\title{
Bird Diversity in Smallholders Oil Palm Plantation in Riau Province
}

\author{
Yanto Santosa*, Anxious Yoga Perdana, Sandi Sopiyandi, Yohanna
}

Bogor Agricultural University, Bogor 16680, Indonesia

\begin{abstract}
Within the last few decades, oil palm (Elaeis guine) has become one of the most rapid crop plantations being widely cultivated in Indonesia. Land clearing for stallholder plantation is made by people, either individually or in group. Forest clearing for planting activities may cause changes to the composition of the ecosystem. Birds have a significant role in the ecosystem, such as pollinators, seed spreader and pest control. It was claimed that bird richness decreases at least $60 \%$ due to changes in land cover into plantations. This claim needs to be further verified. The objective of this study is to identify bird diversity and determine the similarity of the bird community in some smallholder oil palm plantations in Kuantan Singingi, Pelalawan and Siak District in Riau Province. Data collection had been conducted using transect method with length of $1 \mathrm{~km}$ and width of $50 \mathrm{~m}$. Observations were done at 8 smallholder oil palm plantations in the morning from $6: 00$ to $8: 30 \mathrm{pm}$ and in the afternoon from 15:30 to 18:00 pm with 3 times repetition. Data in the study were analyzed by Margalef Index (Dmg), evenness (E) and community similarity (IS). This research showed that there are 22 species of birds from 15 families. The highest value of diversity and richness was in the plantation 1 while the highest evenness was in the plantation 5 . The lowest diversity was in $\mathrm{SH} 5\left(\mathrm{H}^{\prime}=1.79\right)$, the lowest richness was plantation $6(\mathrm{Dmg}=2.50)$ and the lowest evenness value was in the plantation $4(E=0.90)$. The highest value of community similarity recorded between plantation 1-plantation 4 (IS = 0.92) while the lowest was seen between plantation 5-plantation 7 (IS = 0.44). Similar habitat conditions affect the value of the bird community similarity.
\end{abstract}

Keywords: habitat, ecosystem, species richness

\section{INTRODUCTION}

Within the last few decades, oil palm (Elaeis guine) has become one of the most rapid crop plantations being widely cultivated in Indonesia. In 2010, Indonesia had been the greatest exporter of CPO (Crude

${ }^{*}$ Corresponding author:

Ecological and Wildlife Management Division, Department of Forest Resources Conservation and Ecotourism, Faculty of Forestry, Bogor Agricultural University, Bogor 16680, Indonesia.

Email: yantohaurjaya@yahoo.co.id
Palm Oil) in the world with total area of 8 million hectares and had been expected to increase to 12 million hectares in 2020 (Teoh 2010). BPS data (2013) showed that the area of oil palm plantations in Indonesia according the cultivation status was 11.4 million hectares. The changes in land cover to oil palm plantations are not 
carried out by large companies only, but many communities also become oil palm growers. More than $41.2 \%$ of the total oil palm plantations in Indonesia are owned by smallholders (Gatto et al. 2014).

Riau Province is a province with the largest oil palm plantations in Indonesia. The area of oil palm plantations in Riau Province in 2015 was 2.4 million ha or $21.05 \%$ of the total area of oil palm plantations in Indonesia and 1.4 million ha or $58.3 \%$ of the area of oil palm plantations in Riau Province is owned by smallholders (BPS 2015). It is possible that small farmers would dominate palm oil production in Indonesia in the future (Feintrenie \& Levang 2009). Polunin (1997) explains that forest clearing for plantation activities can drive changes in the composition of the ecosystem. Oil palm expansion is often considered responsible for deforestation, decreased biodiversity, increased greenhouse gas emissions, and conflicted over land rights between oil palm companies and local communities (Curran et al. 2004; Koh and Wilcove 2008; Wilcove and Koh 2010; Wicke et al. 2011; Carlson et al. 2012; Tanuwijaya et al. 2012). Bird richness is reduced at least $60 \%$ due to changes in land cover to plantations (Aratrakorn et al. 2006). Smallholder oil palm plantation is considered to have a greater impact for birds. However, research on birds is more often done in private oil plantations and is very seldom to be done in oil palm plantation owned by smallholders. Therefore, it is necessary to undertake research on bird diversity in smallholder oil palm plantations to prove whether it will reduce the diversity of bird species.

The aim of this study was to identify the diversity of bird species and the similarity of bird communities in several oil palm plantations owned by smallholders in the province of Riau. The results of this study can provide scientific data and latest in- formation on the diversity of bird species in oil palm plantations managed by smallholders and provide an alternative of future management actions of bird conservation in oil palm plantations owned by smallholders.

\section{MATERIAL AND METHOD}

The study was undertaken in eight (8) oil palm plantations owned by smallholders (SP) with different status of ownership, in various locations in Riau Province. The locations of smallholder plantations were close to the private oil palm plantations. The study had been conducted from March to April 2016.

The tools used in obtaining the data were location maps, binocular (size 7×35), digital cameras, watch, stationery, tally sheet, GPS, birds guide books in Sumatra, Java, Bali, and Borneo (MacKinnon et al. 1998). Transect method was used to collect data of birds (Figure 1). Each SP had 1 transect with length of $1 \mathrm{~km}$ and width of $100 \mathrm{~m}$. Observation was undertaken during two active foraging periods, in the morning at 06.00 to $08.30 \mathrm{pm}$ and in the afternoon from 15.30 to $18.00 \mathrm{pm}$. The observation was repeated three times. The observed parameters were bird species, the number of birds, encounter time, and bird activity.

Data analysis to calculate the level of bird species diversity was carried out using richness index (Dmg) and evenness index $(E)$. Comparative analysis of the bird's community between different types of land covers was carried out using Sorensen community similarity index (IS). Conservation status was identified to determine the status of protection based on Government Regulation No 7 of 1999 on the preservation of plant and animal species, scarcity, scarcity status according to the IUCN Red list and trade status under CITES Appendix. 


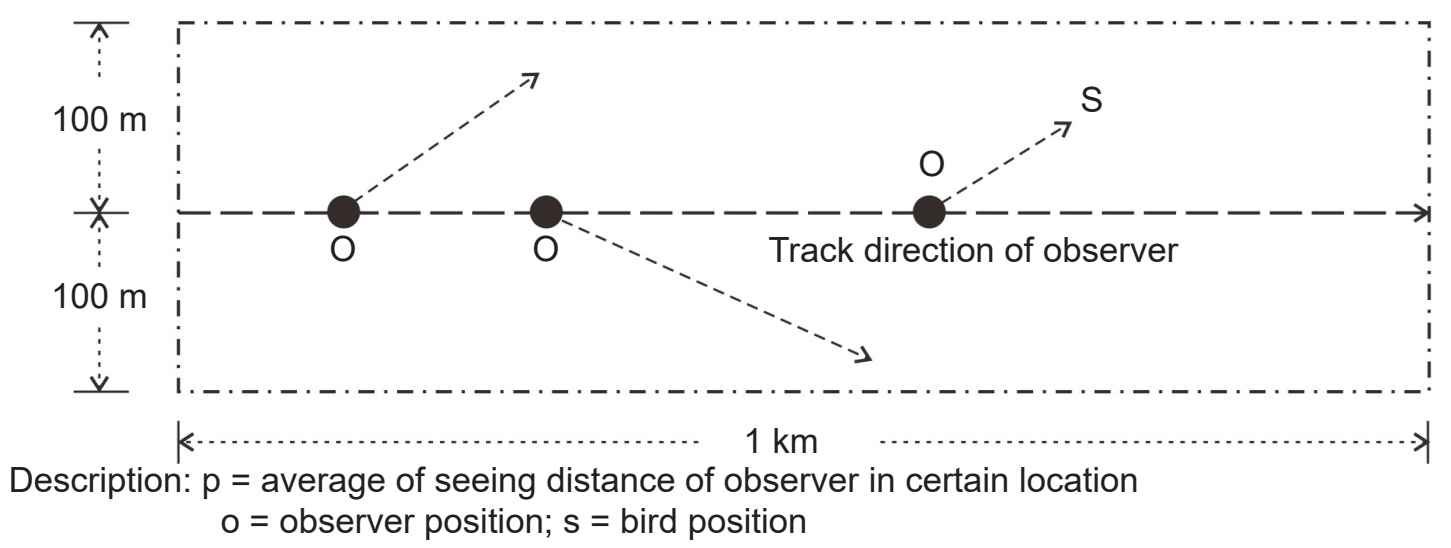

Figure 1 Transect setting of birds observation

\section{RESULTS AND DISCUSSIONS}

\section{General Conditions Research Sites}

The general condition of the location for the study is described in Table 1. The description includes the location of each SP, the owner of the plantation, plant age, state of the plantation, and management performed by the plantation owner.

\section{Variation in Bird Type Diversity, Mar- galef, and Evenness}

In this field study, a total of 22 species of birds from 15 families were found, indicating a high value of diversity, in which the plantation 1 was with the highest Margalef value, while the value of the highest evenness was found in plantation 5 (Table 2 ). Results of the analysis showed that the highest number of species, as many as 12 species of birds were found in plantation 1, plantation 4, and plantation 7 and the highest richness 3.81 was plantation 7. While plantation 5 was a location that had the lowest number of species with six species of birds with species richness index of 2.79. The lowest Margalef was plantation 6 , equal to 2:50. The highest value of evenness was plantation $5(\mathrm{E}=$ $1.00)$ and the lowest was plantation $4(E=$ $0.90)$.
Variations in the value of the analysis were found in this study due to several factors affecting the existence of the bird species. The highest value of species richness found in SP1 is possibly due to the fact that SP1 is a research area that has oil palm plantation with the oldest age compared to other SPs. In addition, SP1 is adjacent to the owner's home that also affect the diversity of birds. Some of the birds found perched and moved from tree to tree or oil palms that were in the yard. Graham (2001) stated that most of the birds found in oil palm plantations often do perching activity. Habitat variations contribute much to the high diversity of the palm (Yoza 2000). The presence of birds in smallholder plantations indicated that the environment was quite favorable for the birds. This result is supported by the discovery of the bird species that acts as seed dispersers (Table 3 ). Ecologically birds have a role in making the cultivation of food crops, seed dispersal and natural pollinators for plants to help farmers, the birds also can be used as biological indicators related to the environment and can be used as a benchmark for sustainability in the use of natural resources (Kinnaird 1997). Group of fruit-eating birds and insects were also found at that location. 
Table 1 The general condition of each oil palm smallholders involved in this study
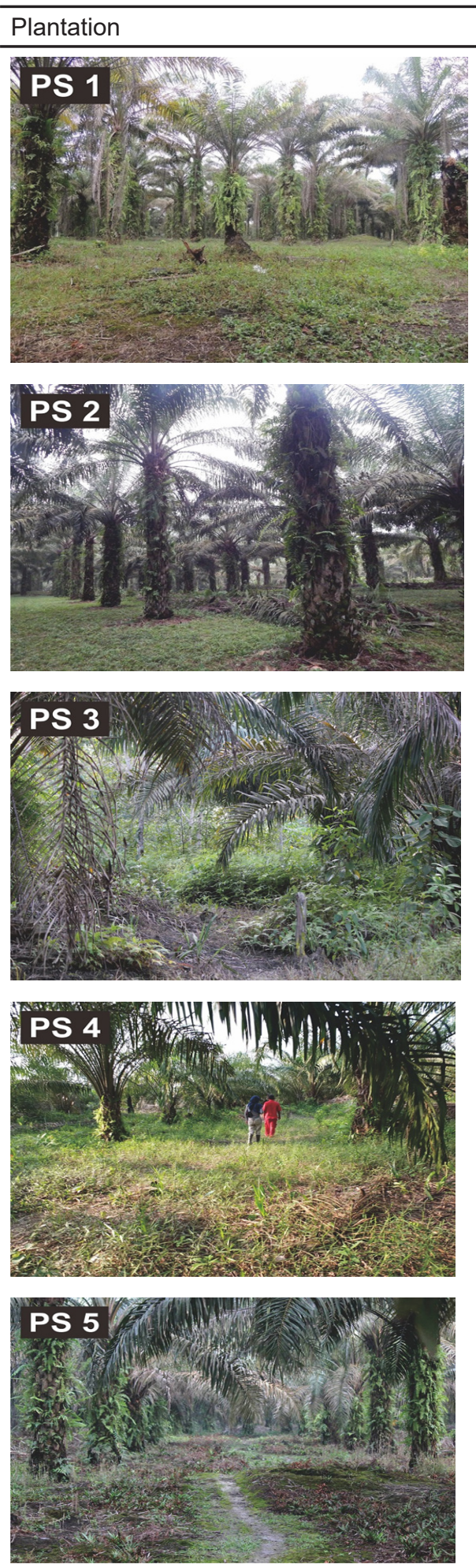

Description

The 1-hectare 17-year-old oil palm plantation adjacent to PT SAR is owned by Mr Turipin. Fertilizing and pruning were conducted three times a year. The plantation was relatively open and rarely cover crops grown. Water resources in these areas were not permanent puddles and exist during the rainy season. The plantation was surrounded by shrubs and rubber plantations. Before planted with oil palm, the land was a crop field.

The 1-hectare 17-year-old plantation located near PT SAR is owned by Mr Sutrisno. Fertilizer application and weeding were conducted three times a year. It was relatively open and under the palm was relatively clean. There was a water source such as a river. The commonly found pest was neetle caterpillar. Previously, the land was reeds.

The 8-hectares 5-year-old plantation located near PT MUP and secondary forests is belonged to Nawawi. There were water sources in the form of a small ditch and pond. In addition, there were some durian trees. The origin of the oil palm plantations was a former farm land of indigenous people. Mr Nawawi managed the plantation independently, learned from what had been done by nearby company.

The 1-hectare 12-year-old plantation adjacent to PT MUP is owned by Mrs Urmi. The plantation is directly adjacent to the main road and a big ditch, and other oil palm plantations. Under the palm trees were relatively open and no water source on it. The origin of the plantation had been in the form of secondary forest/ shrubs and then planted with rubber.

The 1-hectare 11-year-old plantation adjacent to PT GHD is owned by $\mathrm{Mr}$ Hadi. Harvesting was done twice a month, while the fertilizer application was done three times a year. Fertilizer used were urea, kieserit, MoP. While pruning and spraying were done usually twice a year depending on the level of weeds invasion and also cash flow condition. There was a water source in the form of a small ditch. 
Table 1 Continued

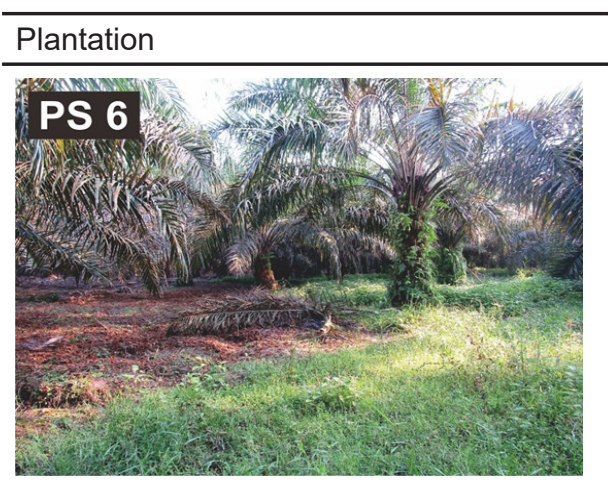

Description

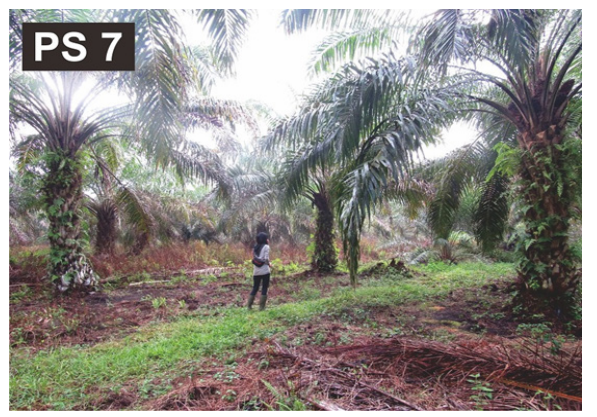

The 1.5-hectare 13-year-old plantation adjacent to PT GHD is owned by Mr Hadi. Fertilization was usually done three times a year with the type of fertilizers used were NPK, urea, TSP. Harvesting was done twice a month. Spraying and pruning were rarely done.

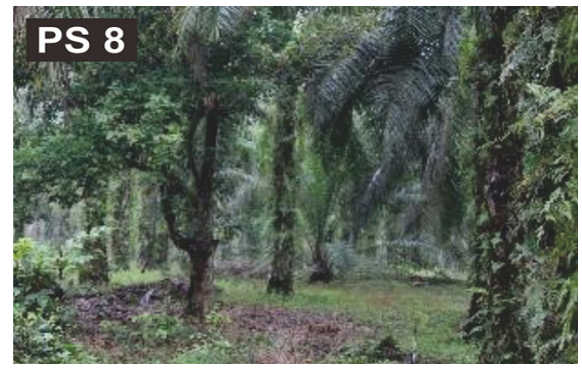

The 2-hectare 22-year-old plantation adjacent to PT IMT is owned by Mr Saringat. Fertilizing and pruning had been conducted every 6 months while spraying had been done every 4 months. The plantation was relatively open and rarely cover crops grown. There was a water source in the form of a big ditch. Soil surface was covered by grass at about $15-30 \mathrm{~cm}$ height. This plantation was once a peat bog. There were large tree stumps on it.

Table 2 Richness, diversity and evenness of birds in the smallholders plantation

\begin{tabular}{crcc}
\hline Plantation & $\mathrm{S}$ & $\mathrm{D}_{\mathrm{mg}}$ & $\mathrm{E}$ \\
\hline 1 & 12 & 3.67 & 0.97 \\
2 & 20 & 3.11 & 0.94 \\
3 & 10 & 3.18 & 0.96 \\
4 & 12 & 3.51 & 0.90 \\
5 & 6 & 2.79 & 1.00 \\
6 & 7 & 2.50 & 0.95 \\
7 & 12 & 3.81 & 0.95 \\
8 & 11 & 3.24 & 0.92 \\
\hline
\end{tabular}

This indicates that the presence of these birds could potentially provide important ecological services to habitat degradation (Sekercioglu et al. 2004). This shows that oil palm plantations owned by smallhold- ers were capable of supporting the existence of several types of birds.

The lowest number of species found in SP5 is probably due to the clearing activity of the plantation floor by the owner, giving a large impact on the presence of birds. Different plantation treatment seemed to influence on the presence of birds among the observed sites. SP plantation with its floor overgrown by shrubs and undergrowth were found to have more bird species than that of plantations with clean floor. This was evidenced by the discovery of insectivorous birds like Centropus bengalensis and Prinia familiaris (Table 3). One of the available feed on oil palm plantations were insects. Availability 
of this feed mode number of birds eating insects become abundant. In the study of Harvey and Haber (1999), the use of shrubs as strata favored by bird in oil palm plantations which makes it important for the preservation of native plants have been lost.

Age of palm trees also affect the level of diversity of birds, and these results are reinforced by Yoza (2000) which stated that the bird diversity index increases with increasing age of the palm trees that caused their habitat variation contained in the oil age levels. In this study it was also found that the older the plantation the higher bird diversity, except if there was an intensive treatment to the plantation made by the owner. Generally, when the age of palm has reached the maximum of fruit production, reduction or discontinuation of treatments such as spraying, weeding, and fertilizing will provide a better condition for the birds as the plantation due to the development of a dense undergrowth causing variations in habitat. This condition had also been expressed by Najera and Simonetti (2010) that the lower vegetation in oil palm plantations improve the abundance and richness of bird communities. The presence of secondary forest adjacent to the plantation also affects the species richness. SP4 with greater species richness is close to a secondary forest where Luck \& Daily

Table 3 List of observed species of birds and its feeding classification in smallholder plantations

\begin{tabular}{|c|c|c|c|c|c|c|c|c|c|c|c|}
\hline \multirow{2}{*}{ No. } & \multirow{2}{*}{ Bird type* } & \multirow{2}{*}{ Scientific name } & \multirow{2}{*}{ Feeding clasification } & \multicolumn{8}{|c|}{ Smallholder plantation } \\
\hline & & & & 1 & 2 & 3 & 4 & 5 & 6 & 7 & 8 \\
\hline 1 & Bondol haji & Lonchura maja & Granivore & 0 & 1 & 0 & 0 & 0 & 0 & 0 & 0 \\
\hline 2 & Bondol peking & Lonchura punctulata & Granivore & 0 & 0 & 0 & 0 & 0 & 0 & 0 & 1 \\
\hline 3 & Bubut alang-alang & Centropus bengalensis & Insektivore Frugivore & 1 & 2 & 1 & 1 & 1 & 1 & 2 & 2 \\
\hline 4 & Bubut besar & Centropus sinensis & Insektivore Frugivore & 2 & 0 & 1 & 1 & 0 & 0 & 0 & 0 \\
\hline 5 & $\begin{array}{l}\text { Burung-gereja } \\
\text { Erasia }\end{array}$ & Passer montanus & Granivore & 2 & 2 & 0 & 2 & 1 & 0 & 0 & 0 \\
\hline 6 & $\begin{array}{l}\text { Burung-madu } \\
\text { sriganti }\end{array}$ & Nectarinia jugularis & Nektarvore Frugivore & 2 & 0 & 0 & 0 & 0 & 0 & 0 & 0 \\
\hline 7 & Cabak maling & Caprimulgus macrurus & Insektivore & 0 & 0 & 0 & 0 & 0 & 0 & 0 & 1 \\
\hline 8 & Cangak merah & Ardea purpurea & Granivore & 0 & 0 & 0 & 0 & 0 & 0 & 0 & 0 \\
\hline 9 & Cekakak belukar & Halcyon smyrnensis & Piscivore & 1 & 1 & 2 & 1 & 1 & 1 & 2 & 2 \\
\hline 10 & Cinenen kelabu & Orthotomus ruficeps & Insektivore & 2 & 3 & 3 & 2 & 0 & 1 & 1 & 1 \\
\hline 11 & Cucak kutilang & Pycnonotus aurigaster & Insektivore & 1 & 4 & 3 & 1 & 0 & 0 & 0 & 2 \\
\hline 12 & Gagak hutan & Corvus enca & Omnivore & 0 & 0 & 0 & 0 & 1 & 0 & 0 & 0 \\
\hline 13 & Kerak kerbau & Acridotheres javanicus & Omnivore & 0 & 0 & 0 & 0 & 0 & 0 & 1 & 0 \\
\hline 14 & Kipasan belang & Rhipidura javanica & Insektivore & 0 & 0 & 0 & 0 & 0 & 0 & 1 & 1 \\
\hline 15 & Kuntul kerbau & Bubulcus ibis & Karnivore & 0 & 0 & 0 & 1 & 0 & 0 & 0 & 0 \\
\hline 16 & Merbah cerukcuk & Pycnonotus goiavier & Omnivore & 3 & 2 & 1 & 2 & 0 & 2 & 1 & 6 \\
\hline 17 & Perenjak jawa & Prinia familiaris & Insektivore Frugivore & 2 & 1 & 2 & 7 & 1 & 2 & 1 & 3 \\
\hline 18 & Perenjak rawa & Lonchura malacca & Insektivore Frugivore & 0 & 0 & 0 & 0 & 0 & 0 & 1 & 0 \\
\hline 19 & Perkutut jawa & Geopelia striata & Frugivore Granivore & 1 & 1 & 1 & 1 & 1 & 1 & 2 & 1 \\
\hline 20 & Serak jawa & Tyto alba & Karnivore & 0 & 0 & 0 & 0 & 0 & 0 & 1 & 0 \\
\hline 21 & Tekukur biasa & Streptopelia chinensis & Frugivore Granivore & 2 & 1 & 2 & 2 & 0 & 0 & 4 & 2 \\
\hline 22 & Walet sapi & Collocalia esculenta & Insektivore & 1 & 0 & 1 & 2 & 0 & 3 & 1 & 0 \\
\hline
\end{tabular}

*The order of the names of birds on a breadcrumb based Sukmantoro et al. 2007 but to facilitate the reader it is based on alphabetical order 
(2003) stated that individual birds tend to exploit food resources are located close to the forest habitat.

Variations in the value of the Margalef of bird species are influenced by a large number of species and the total number of individuals of species found at each observation location. Creatures will choose a habitat that has an abundance of resources for survival, otherwise rarely or never found in a less favorable environment for him (Wyne-Edwards 1972). In addition, the level of human presence in the plantation could also become a factor in determining the abundance of birds in smallholder plantations. The average owner visitation for harvesting activity was only once in two weeks. According to Meffe and Carrol (1994) disorder with low to medium levels in an ecosystem will increase the Margalef of species that live in it. Similar finding was also revealed by Widodo (2009) that the habitat in good condition and away from human disturbance, contains a variety of feed resources and has a lot of bird species.

Variations of evenness index value of each SP was quite high, approaching 1. Distribution of birds in the whole study sites (SPs) can be said to be stable because the index value of evenness $(E)$ of the birds close to 1 . The highest Value of bird evenness was found in SP5 (1.00) and the lowest evenness is in SP4 (0.90). SP4 have a greater number of species than SP5. Uneven number of individuals of each species affect the evenness values. This condition is in line with opinion of Ludwig \&Reynolds (1988) which stated that the value of equity is affected by the number of species present in a community. In this study it had been found that there were no dominant species of the bird as the value of fairness approaches 1. The high value of fairness indicates that smallholders have sufficient feed to meet the needs of the birds and the absence of competition that led to the emergence of a dominant species. These results were confirmed by Kurnia et al. (2005) which stated that the higher the value of equity indices, indicating that in a community there is no dominant species.

\section{Bird Community Similarity}

Community similarity index was used to determine the relative similarity of the species composition of the two compared communities (Magguran 1988). Bird species similarity index shows how much similarity between bird communities in the observation location. The same community visits with the presence of the same type on the two habitats were comparable (Santosa et al. 2008). Comparison similarity to eight communities in their fields have values that are quite varied ranging from 0.44 to 0.92 (Table 4).

Sorensen similarity index was seen at SP1-SP4 with index value of 0.92 (Table $4)$. The highest value of similarity between SP1 and SP4 communities is probably due to the similarity of the plantation condition such as relatively open canopy and clean plantation floor. Hubbell \&Foster (1986) stated that the areas where the environmental conditions are not so different that does not seem to have different communities. While the lowest similarity index was found between SP5 and SP7 that is equal to $0: 44$. The low value of the index influenced the similarity of their differences in habitat conditions that support bird life such as food resources or diversity of vegetation as shelter and nesting. Farimansyah (1981) stated that a high diversity of vegetation types is thought to provide a source of food, shelter and nesting place of bird species. Similarly, Orians (1969) who found the bird species diversity is influenced by many factors, including the abundance of epiphytes, an abundance of fruits, the openness of the forest floor and tree species composition. 
Table 4 Community similarity index among smallholder's plantation

\begin{tabular}{|c|c|c|c|c|c|c|c|}
\hline $\begin{array}{l}\text { Sorensen SP1 } \\
\text { index }\end{array}$ & SP2 & SP3 & SP4 & SP5 & SP6 & SP7 & SP8 \\
\hline SP1 & 0.82 & 0.91 & 0.92 & 0.56 & 0.74 & 0.67 & 0.70 \\
\hline SP2 & & 0.80 & 0.82 & 0.63 & 0.71 & 0.64 & 0.76 \\
\hline SP3 & & & 0.91 & 0.50 & 0.82 & 0.73 & 0.76 \\
\hline SP4 & & & & 0.56 & 0.74 & 0.67 & 0.70 \\
\hline SP5 & & & & & 0.62 & 0.44 & 0.47 \\
\hline SP6 & & & & & & 0.74 & 0.67 \\
\hline SP7 & & & & & & & 0.70 \\
\hline SP8 & & & & & & & \\
\hline
\end{tabular}

The availability of food in a type of habitat is one of the main factors for the presence of bird populations (Wiens 1992). SP1 can support the needs of diverse bird habitat than SP5. This is evident from the number and species of birds present is quite different that the index value of the similarities in the two SP lower. However, the effect of changes in the composition and structure of vegetation can jointly determine the diversity of bird species in some managed lands (Grundel \& Pavlovic 2008).

\section{Bird Conservation Status}

Basically, oil palm plantations owned by smallholders have conservation value that are quite important for several species of birds. This can be seen from the bird species found in the list of PP No.7 1999 on the preservation of animals and plants and Appendix II under CITES trade status. Plantation is also a habitat for birds to be able to survive. The bird ability to live in conditions of oil palm plantations indicating that the birds are tolerant with the existing conditions of the smallholder plantations. Yoza (2000) stated that plantations have an important role in the conservation of birds, especially for birds love the open condition. In this research, it was recorded 4 bird species protected under Regulation 7 of 1999 and one bird species in the list of Appendix II by CITES trade status is Tyto alba. The birds are natural predators, known to be very effective and specific in the control of mice (Kuswardhani 2006). In Israel, this bird has been developed for the control of mice and other rodent pests on land / vineyard and palm groves (Levi 2011). Bird species recorded only classified as low risk in the IUCN Red list.

\section{CONCLUSION}

The level of richness and evenness of bird varies in each smallholder plantation. The highest species richness was found in SP1 while the highest evenness was in SP5. The lowest Margalef value was found in SP6 (Dmg = 2.50) and the lowest value of evenness was found in SP4 (E $=0.90)$. SP age classes affect the level of diversity of bird species in which the older the oil palm plantations then, biodiversity was also higher. The highest bird community similarity was found between SP1-SP4 (IS = 0.92) while the lowest was seen between SP5-SP7 (IS = 0.44). Habitat conditions similarity affects the value of the bird community similarity.

\section{REFERENCES}

Aratrakorn S, Thunhikorn S, Donald PF. 2006. Changes in bird communities following conversion of lowland forest to oil palm and rubber plantations in 
southern Thailand. Bird Conservation International. 16(1):71-82.

[BPS] Badan Pusat Statistik. 2013. Luas Areal Perkebunan menurut Jenis Tanaman. Diunduh dari http://riau.bps.go.id/ linkTabelStatis/view/id/149 pada tanggal [Juli 28 2016].

Carlson KM, Curran LM, Ratnasari D, Pittman AM, Soares-Filho BS, Asner GP. 2012. Committed carbon emissions, deforestation, and community landconversion from oil palm plantation expansion in West Kalimantan, Indonesia. Proc Natl Acad Sci. 109(19):7559_ 7564.

Curran LM, Trigg SN, McDonald AK, Astiani D, Hardiono YM, Siregar P. 2004. Lowland forest loss in protected areas of Indonesian Borneo. Science 303:1000-1003.

Farimansyah. 1981. Keanekaragaman Jenis Burung Pada Berbagai Lingkungan di Bogor dan Sekitarnya.[Skripsi]. Bogor (ID): Institut Pertanian Bogor.

Feintrenie L, Levang P. 2009. Sumatra's rubber agro-forests: advent, rise and fall of a sustainable cropping system. Small-Scale Forestry. 8(3):323-335.

Gatto M, Wollni M, Qaim M. 2014. Oil palm boom and land-use dynamics in Indonesia: the role of policies and socio-economic factors. Goettingen (GM): EFForTS Discussion Paper 6.

Graham CH. 2001. Factors influencing movement patterns of Keel-billed Toucans in a fragmented tropical landscape in southern Mexico. Conserv Biol. 15(2001):1789-1798.

Grundel R, Pavlovic BN. 2008. Using Conservation Value to Assess Land Restoration and Management Alternatives Across A Degraded Oak Savanna Landscape. J Appl Ecol. 45(2008):315324.

Harvey CA, Haber WA. 1999. Remnant trees and the conservation of biodiver- sity in Costa Rican pastures. Agroforestry Systems. 44(1999):37-68.

[IUCN] International Union for Conservation of Nature. 2015. IUCN Red List of Threatened Species. Diunduh dari www.redlist.org pada tangal [Juli 28 2016].

Kinnaird MF. 1997. Sulawesi Utara: sebuah panduan sejarah alam. Jakarta (ID): Yayasan Pengembangan Wallaceae.

Koh LP, Wilcove DS. (2007). Cashing in palm oil for conservation. Nature. 448:993-994.

Krebs CJ. 1989. Ecological Methodology. London (UK): Harper and Row Publishers.

Kurnia, IH. Fadly, U. Kusdinar, WG. Gunawan, DW. Idaman, RS. Dewi, D. Yandhi, GS. Saragih, GF. Ramadhan, TD. Djuanda, R. Risnawati. Firdaus, M. 2005. Keanekaragaman Jenis Burung di Taman Nasional Betung Kerihun Kabupaten Kapuas Hulu. Provinsi Kalimantan Barat (ID). Media Konservasi; p. 37-46.

Kuswardhani SA. 2006. Evaluasi Hasil Introduksi Tyto alba javanica (Gmel) Pemangsa Tikus di Ekosistem Persawahan Kabupaten Kendal, Jawa Tengah. J Penelitian Bidang IImu Pertanian. 4(2): Agustus 2006.

Levi M. 2011. Organic Agriculture. Kibbutz-Israel.

Luck GW, Daily GC. 2003. Tropical countryside bird assemblages: richness, composition, and foraging differ by landscape context. Ecol Appl. 13(2003):235-247.

Ludwig JA, Reynolds JF. 1988. Statistical Ecology: A Primer on Methods and Computing. New York (UK): John Wilwy and Sons.

MacKinnon J, Phillipps K, van Balen B. 1998. Seri panduan lapangan burungburung di Sumatera, Jawa, Bali dan 
Kalimantan. Bogor (ID): Bird life International-Indonesia Program - Pusat Penelitian dan Pengembangan Biologi LIPI.

Magurran A.1988. Global Forest Resource. London (UK): Belhaven Press; p. 201-209.

Magurran AE. 1998. Ecological Diversity and its Measurement. New Jersey (UK). Princeton University Press.

Margono BA, Turubanova S, Zhuravleva I, Potapov P, Tyukavina A, Baccini A. 2012. Mapping and monitoring deforestation and forest degradation in Sumatra(Indonesia) using Landsat time series data sets from 1990 to 2010. Environ Res Lett. 7(3):034010.

Meffe GK, Carrol CR. 1994. Principles of Conservation Biology. Sunderland (IT): Sinnauer Associates Inc.

Najera A, Simonetti JA. 2010. Can oil palm plantations become bird friendly. Agro for Syst. 80(2010): 203-309.

Orians GH. 1969. The Number of Birds Species in Some Tropical Forest. Japan (JP): Saunders College Pub.

Polunin, N. 1997. Teori Ekosistem dan Penerapannya. Yogyakarta (ID): Gadjah Mada University Press; p. 195-197.

Santosa Y, Eko PR, Dede AR. 2008. Studi Keanekaragaman Mamalia pada Beberapa Tipe Habitat di Stasiun Penelitian Pondok Ambung Taman Nasional Tanjung Puting Kalimantan Tengah. Media Konservasi. 13:1-7.
Sekercioglu CH, Daily GC, Ehrlich PR. 2004. Ecosystem consequences of bird declines. Proceedings of the National Academy of Sciences USA. 101(2004):18042-18047.

Sukmantoro W, Irham M. 2007. Daftar Burung Indonesia no. 2. Bogor (ID): Indonesian Ornothologists" Union.

Teoh CH. 2010. Key Sustainability Isues in the Palm Oil Sector: A Discussion Paper for Multi-Stakeholders Consultations. Washington DC (UK): Internastional Finance Corporation, World Bank.

Wicke B, Sikkema R, Dornburg V, Faaij A. 2011. Exploring land use changes andthe role of palm oil production in Indonesia and Malaysia. Land Use Policy. 28(1):193-206.

Wiens JA. 1992. The Ecology of Bird Communities. Cambridge (GB): University Press Foundations and Patterns.

Wilcove DS, Koh LP. 2010. Addressing the threats to biodiversity from oil-palmagriculture. Biodivers Conserv. 19(4):999-1007.

Wyne EVC. 1972. Animal Disperson in Relation to Social Behaviour. New York (UK): Hafner Publishing Company Inc.

Yoza D. 2000. Dampak Perkebunan Kelapa Sawit Terhadap Keanekaragaman Jenis Burung Di Areal Perkebunan PT Ramajaya Pramukti Kabupaten Dati II Kampar Provinsi Dati I Riau [disertasi]. Bogor (ID): Institut Pertanian Bogor. 